\title{
INFECTIVITY AND MULTIPLICATION OF NOSEMA APIS Z. IN THE VENTRICULUS OF THE HONEY BEE
}

\author{
Ingemar FRIES \\ Bee Division, Swedish University of Agricultural Sciences, \\ $S-75007$ Uppsala, Sweden
}

\section{SUMMARY}

Spores of Nosema apis were individually fed to groups of 100 adult worker honey bees (Apis mellifera) at doses of $6.25 \times 10^{3}, 6.25 \times 10^{2}, 6.25 \times 10^{1}, 6.25 \times 10^{0}, 6.25 \times 10^{-1}$ and 0 spores per bee respectively. The caged bees were kept in incubator at $+30^{\circ} \mathrm{C}$.

Spore levels detectable in a hemacytometer were produced 4 days p.i. At fifteen days p.i. the mean spore count per infected bee exceeded $18 \times 10^{6}$ in all groups in which infection was found. The highest spore count in an individual bee was $38.3 \times 10^{6}$.

Irrespective of infection dose, approximately the same level of infection was reached in the infected bee within 2 weeks. High spore doses produced fully developed infections slightly sooner. Only the dose of $6.25 \times 10^{3}$ spores per bee produced $100 \%$ infection. The median infective dose was calculated to 94,3 spores/bee with a $95 \%$ confidence intervall between 29.0 to 344.0 spores/bee.

In histological sections prepared from ventriculi 2, 4, 6 and 8 days p.i. the infection normally seemed to spread from the posterior to the anterior parts of the ventriculus.

\section{INTRODUCTION}

The microsporidian Nosema apis infects the epithelial cells in the ventriculus of the honey bee, Apis mellifera. The spore produced by the parasite is the infective agent between individual honey bees. According to BaILEY (1981), comb soiled with feces is the primary source of infection. Although the disease caused by $N$. apis might seriously damage honey bee colonies in temperate climates, the importance of spore dose for the infectivity and further development of the disease has received little attention.

Spores from $N$. apis are ingested by the honey bee and reach the ventriculus within 5-10 minutes (KelLner \& JACOBS, 1978) after ingestion. With a heavy inoculum some spores will remain longer in the proventriculus (VERBEKE et al., 1984). The majority of spores germinate shortly after entering the ventriculus, however viable spores that have not yet germinated can still be 
recovered from the ventriculus 2 hours after feeding bees with $N$. apis spores (BAILEY, 1955).

Bailey $(1972 a, b)$ found the median infective dose to be below 100 spores for $N$. apis and was able to infect worker bees using single spore inoculations. Lotmar (1940) needed 1000 spores/bee to produce $N$. apis infections in $28 \%$ of the tested animals. Estimates for $N$. algerae infecting Anopheles albimanus (AvERy \& ANTHONY, 1983) and N. fumiferanae infecting Choristoneura fumiferana (WILSON, 1983) indicate that much higher spore numbers are needed to create infection. In the microsporidian Vairimorpha necatrix infecting Trichoplusia $n i$ however, doses as low as 11 spores have been shown to kill over $50 \%$ of the host larvae (Chu \& JAQues, 1981). Observations of the initial site of $N$. apis infection and spread within the ventricular epithelium differ among authors. BAILEY (1955) found vegetative stages throughout the ventricular epithelium, with infection peaks in the anterior as well as the posterior parts 48 hours after infection. Muresan et al. (1975) also found the infection evenly spread in the epithelium. Liv (1984) claims that the infection is spread from the anterior to the posterior ventricular parts. In contrast, Kellner (1980) found the growing infection to spread from the posterior to the anterior parts of the ventriculus.

LOTMAR (1940) began quantitative determinations of $N$. apis spore levels in the honey bee using hemacytometer counts. This method of describing infection level has been adopted by a number of authors (Burnside \& Revell, 1948 ; Bailey, 1955 ; 1959 ; 1968 ; 1972a ; b ; L'Arrivée, 1963 ; 1966 ; GoNtarski \& Mebs, 1964 ; Rinderer \& Elliott, 1977 ; Lehnert \& Shimanuki, 1979 ; FINGLER et al., 1982 ; Fries et al., 1984) and was described in detail by Cantwell (1970). Van Laere et al. (1980) investigated the precision of estimating $N$. apis spore numbers by hemacytometer counts.

LotMAR (1943) found that $N$. apis infections are fully developed after about 10 days with about $44 \times 10^{6}$ spores in the ventriculus at $+30^{\circ} \mathrm{C}$. In the same experiment the rectum contained about $240 \times 10^{6}$ spores 42 days postinfection (p.i.). BAILEY (1981) states that $35-50 \times 10^{6}$ spores in the ventriculus represents a fully developed infection, while Furgala \& Mussen (1978) mention that quantitative measurements of nosema spores may reach $180 \times$ $10^{6}$ spores per bee, probably referring to collective samples of whole bees. WeISS (1984) reports that $250 \times 10^{6}$ spores have been found in the ventriculus of the honey bee. According to BAILEY (1959) « a quantitative relationship exists between number of spores fed to a bee and number of spores that develop ».

The time between spore ingestion and formation of new spores varies with temperature (Lotmar, 1943). At $+30^{\circ} \mathrm{C}$, Lotmar (1943) reported 6 days, 
Bailey (1981) 5 days, Jacobs et al., (1978) 4-6 days and Kellner (1980) 2 days for the parasite to complete its development within the host cell. The purpose of this study was to investigate the increase in number of spores of $N$. apis in the ventriculus of the honey bee following inoculation with various spore doses and to clarify the relation between spore dose and infectivity.

\section{MATERIAL \& METHODS}

Sealed brood combs with mature pupac from colonies resembling the black bee Apis mellifera mellifera, were incubated at $+34^{\circ} \mathrm{C}$. Newly emerged bees were collected at 24 hour intervals. The bees were kept in cages similar to Kulincevic et al. (1973) in an incubator at $+30^{\circ} \mathrm{C}, 50 \% \mathrm{RH}$ and were supplied with fresh bee-collected pollen in a container inside the cage and sucrose in water solution $1 / 1$ $(w / w)$ ad. lib. through a gravity feeder. When seven days old, the bees were used for infectivity tests.

$N$. apis spores were obtained by removing the ventriculus from live infected bees and triturating the ventriculus in water (BAILEY, 1972a). Mature spores as defined by LoTMAR (1943) were counted using a hemacytometer (Bürker, $1 / 400 \mathrm{ccm}$, Tiefe $0.1 \mathrm{~mm}$ ) following the procedure of CANTwELL (1970) but counting 24 squares of $1 / 25 \mathrm{~mm}^{2}$ in a diagonal pattern. A stock solution containing $6.25 \times 10^{5}$ spores $/ \mathrm{ml}$ was prepared. From this solution serial dilutions were made containing $6.25 \times 10^{4}, 6.25 \times 10^{3}, 6.25 \times$ $10^{2}$, and $6.25 \times 10^{1}$ spores/ml sugar solution. The solutions were kept at $-28^{\circ} \mathrm{C}$ for 1 day $(6.25 \times$ $\left.10^{5}\right), 2$ days $\left(6.25 \times 10^{3}, 6.25 \times 10^{1}\right)$ and 3 days $\left(6.25 \times 10^{4}, 6.25 \times 10^{2}\right)$ respectively before they were used. For each solution 100 bees, 7 days old, were individually fed $10 \mu$ yielding groups of bees receiving $6.25 \times 10^{3}, 6.25 \times 10^{2}, 6.25 \times 10^{1}, 6.25 \times 10^{0}$ and $6.25 \times 10^{-1}$ spores/bee. One hundred bees kept as control received sucrose solution through the gravity feeder. Before feeding, the bees were starved for 2-3 hours. The $10 \mu \mathrm{l}$ solution was supplied to each bee with a micro constriction pipette (Pedersen, Denmark) while the bee was held by its wings. Bees that did not readily accept the food were discarded. After feeding, the different groups of bees were kept at $+30^{\circ} \mathrm{C}$ and $50 \% \mathrm{RH}$ in cages similar to Kulincevic et al. (1973).

From a separate stock solution, also containing $6.25 \times 10^{5}$ spores $/ \mathrm{ml}, 20$ bees were fed $10 \mu \mathrm{l}$ $\left(6.25 \times 10^{3}\right.$ spores/bee). These bees, infected for histological preparations, were kept under the same conditions as the rest of the infected bees.

Beginning with the first day p.i. and for each day thereafter, 5 bees from each group were sampled. The ventriculus of each bee was removed and separated from the proventriculus and the small intestine at the site of Malpighian tubules. Each ventriculus was triturated in $0.1 \mathrm{ml}$ water and examined for mature spores in a hemacytometer as previously described. When spore numbers exceeded $5-10$ spores $/ 24$ squares the samples were diluted to $1 \mathrm{ml}$. Using $1 \mathrm{ml}$, the samples were diluted to 5 or $10 \mathrm{ml}$ when spore counts exceeded $10-15$ spores/square to facilitate counting. On the 15 th day p.i. the remaining bees in all groups were examined for the presence of nosema infection.

From the 20 bees fed $6.25 \times 10^{3}$ spores from the second stock solution, samples of 3 bees were removed at 2, 4, 6 and 8 days p.i. The ventriculi of these bees were fixed for 2 hours in cacodylate buffered $4 \%$ glutaraldehyde solution ( $\mathrm{pH} 7.2$ ), stored in cacodylate buffer for one week and embedded in Historesin after dehydration in an ethanol serie. Serial sagittal sections with a thickness of $2 \mu$ were cut using a microtome. The sections were permanently mounted after contrast coloring with toluidine. The preparations were examined in a Zeiss light microscope at $\times 160-640$ magnification. 


\section{RESULTS}

From the 4th day p.i. the average spore number in the ventriculus increased rapidly. The average spore count/bee on the 15 th day p.i. exceeded $1.8 \times 10^{7}$ in the 4 groups with the largest inoculum. No infection was found in the other groups at this sampling time. The highest spore count in a single bee was $3.8 \times 10^{7}$. The increase in number of mature spores for the largest spore dose can be seen in fig. 1. Besides an initial faster increase in spore levels in this group, the development was similar in bees receiving lower spore doses. The first observation of a mature spore with earlier developing stages present was made on day 3 in this group. This was a single spore observation in one of the 5 bees sampled. Two bees with single spore observations 2 days p.i., with no visible young spores or sporonts, in the groups given $6.25 \times 10^{3}$ and $6.25 \times 10^{1}$ spores/bee respectively, were not regarded as infected. From the 4th day p.i. mature spores were found in the group receiving most spores in all bees in the daily 5 bee samples. Thus, disregarding single spore observations, detectable levels of mature spores were produced after 4 days in this investigation. From the 5th day p.i. mature spores were found each day in one or more of the bees receiving $6.25 \times 10^{2}$ and $6.25 \times 10^{1}$ spores/bee. No

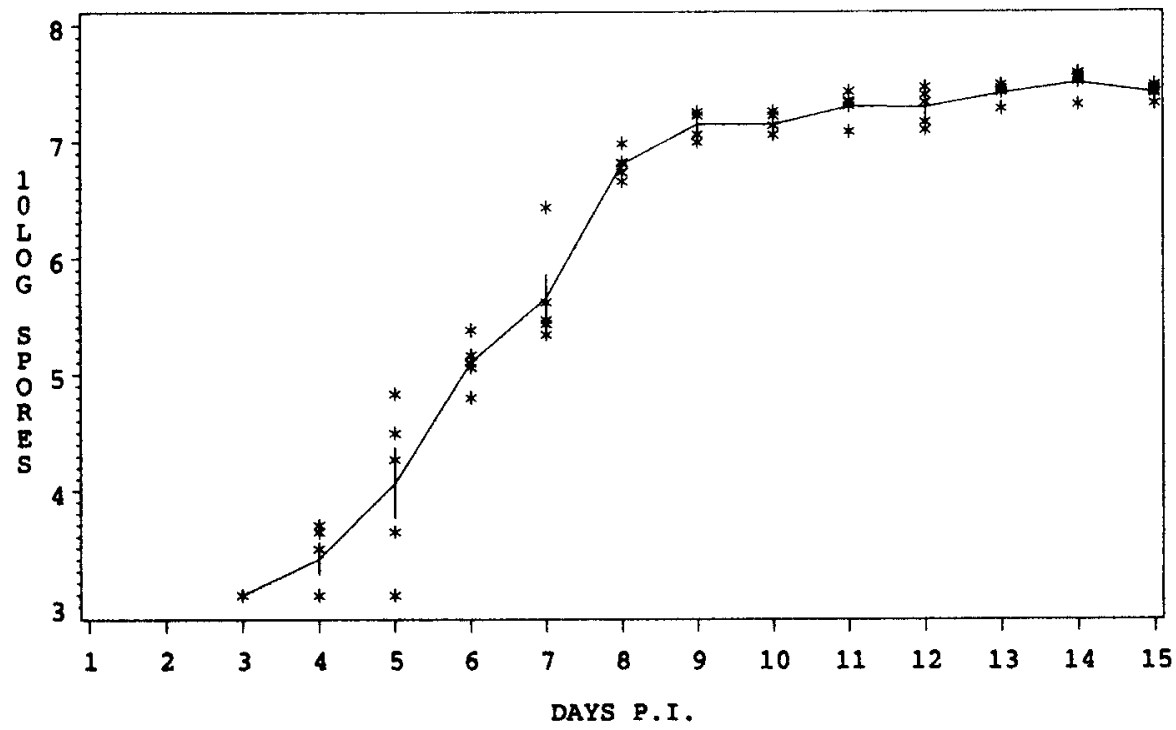

Fig. 1. - Log10 number of mature N. apis spores in the ventriculus of honey bees at various times p.i. following a $6.25 \times 10^{3}$ spore dose. The unbroken line represents mean spore count per infected bee $(n=5)$ and the vertical lines show standard error of mean (SEM) at each sampling time. 
significant difference in infection level of infected bees could be found between the groups 11 to 15 days p.i. From 4 to 10 days p.i. the samples from the group with the largest inoculum had significantly higher average spore counts/ bee than the other groups $(p<0.05)$ except on day 6 .

The relationship between dose, time and infection level can be seen in fig. 2. The figure demonstrates that, irrespective of infection dose, approximately the same level of infection is reached within 2 weeks. No infected bee was found in the control group.

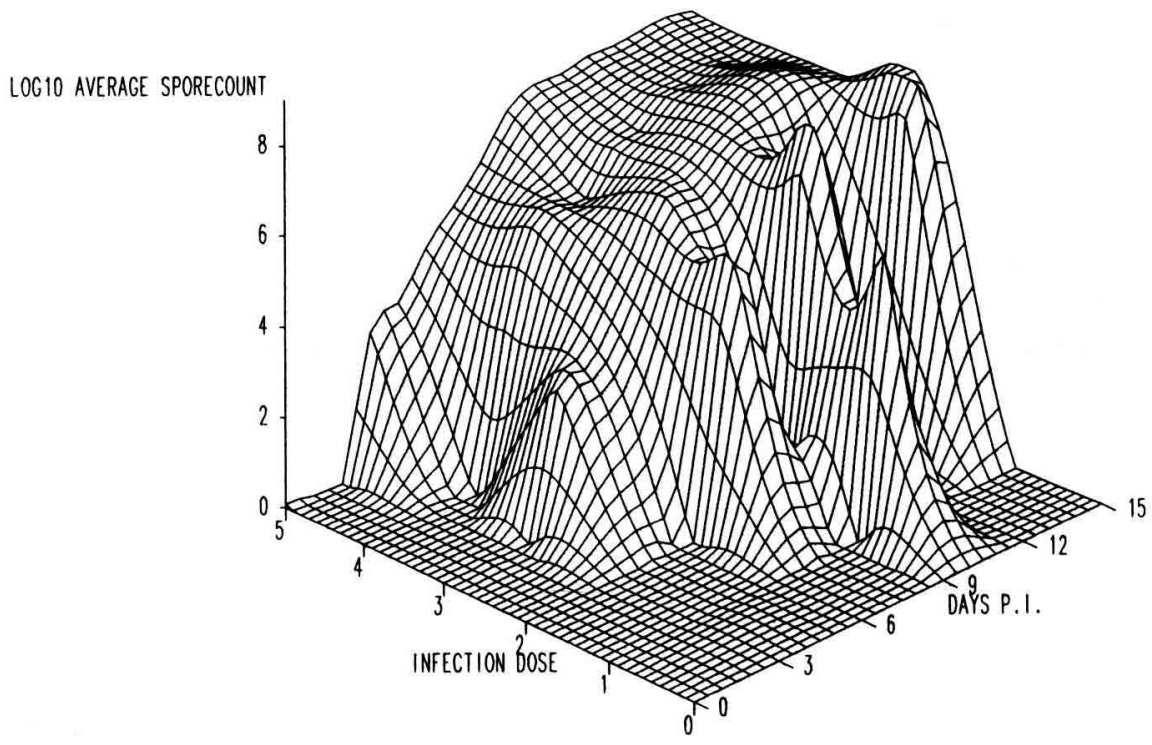

FIG. 2. - The relation between infection dose, time and infection level. Log10 dose has been used except for dose $=0$. Dose $0,1,2,3,4,5,=0,6.25 \times 10^{-1}, 6.25 \times 10^{0}, 6.25 \times 10^{1}, 6.25 \times 10^{2}$ and $6.25 \times 10^{3}$ spores/bee respectively.

The relationship between the dose and infection percentage can be seen in fig. 3. The median infective dose $\left(\mathrm{ID}_{50}\right)$ was calculated to 104.4 spores using probit analysis (Finney, 1971) but with $\mathrm{p}<0.1$ for chi-square. Thus the model using probit transformed percentage was discarded. The regression between infected percentage and $\log 10$ spore dose in fig. 3 shows an $\mathrm{ID}_{50}$ of 94.3 spores/bee in a $95 \%$ confidence intervall of 29.0 to 344.0 spores/bee (RAo, 1973). To determine the number of infected bees in each group the results from the 7 th day p.i. and later were included. 


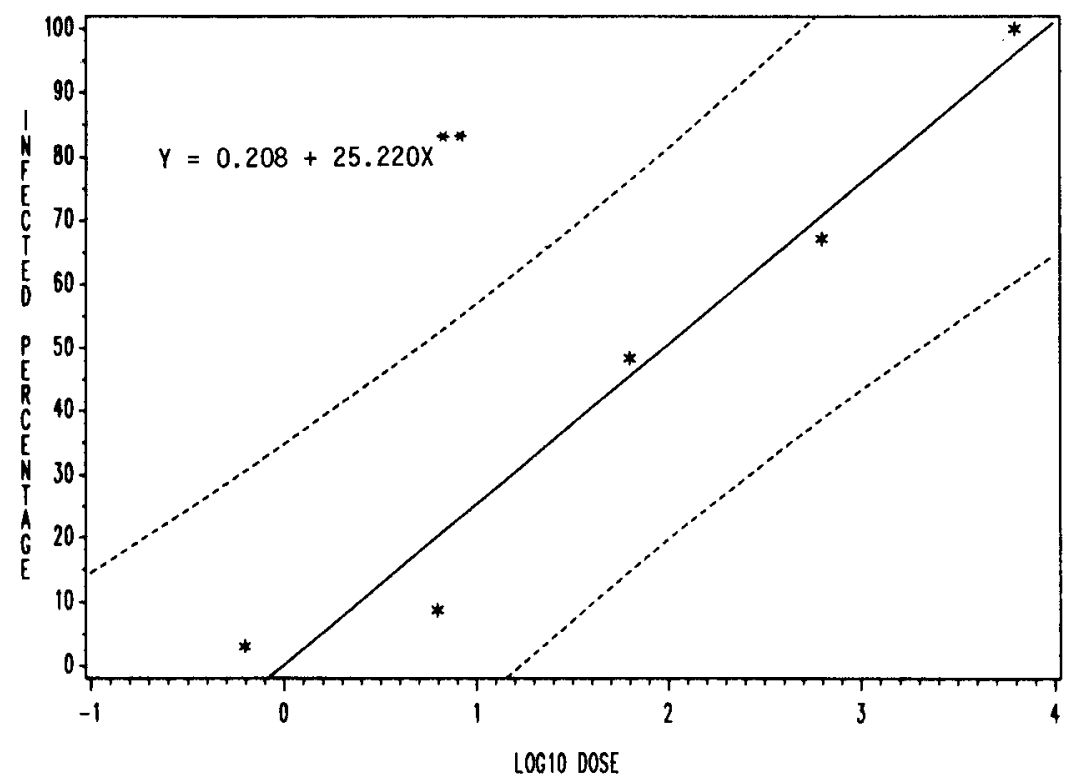

Fig. 3. - Regression of percentage infected bees vs log10 spore dose. The two outer lines represent the $95 \%$ confidence limits for individual predicted values. From left to right $n=67,64,68$ and 65 respectively for the plotted observations. ${ }^{* *} \mathrm{p}<0.01$.

\section{DISCUSSION}

Only BaILEY (1972a ; b) has previously investigated the median infective dose of $N$. apis $\left(\mathrm{ID}_{50}\right)$. He stated that it is below 100 spores (1972a) and 21 spores for fresh material (1972b). The spore suspensions used in this experiment were frozen for 1-3 days but this should not influence the viability of nosema spores significantly (BAILEY, 1972b ; MoffetT \& Wilson, 1971). The slight discrepancy with earlier investigations concerning spore counts as well and $\mathrm{ID}_{50}$ value, might be explained by differences in susceptibility of the bees, differences in spore viability, or both. Bacterial contamination of the inoculum might influence the infectivity of $N$. apis (FrIEs, unpublished data) and the availability of proteins for the host also affects disease development (GoNTARSKI \& MeBS, 1964 ; Rinderer \& ElLIOTT, 1977).

Although the results of BAILEY (1972a ; b), where single spore inoculations could produce infection, are confirmed in this study, it is reasonable to believe that a larger number of spores normally are necessary to produce infection. The spores may need to be oriented in a certain direction in the lumen for the extruded polar filament to penetrate an epithelial cell. If randomly oriented, 
many spores will leave their sporoplasm in the gut lumen where the parasite soon will be damaged by the digestive fluids (Avery \& ANTHONy, 1983). For the polar filament to penetrate an epithelial cell, the spore probably has to germinate less than $400 \mu$ from the gut wall (Morgenthaler, 1963). Information on $N$. algerae (Avery \& ANTHONY, 1983) and $N$. fumiferanae (Wilson, 1983) infectivity suggests that significantly larger spore doses are required to produce infection in their respective hosts. However, $\mathrm{ID}_{50}$ values below 100 spores have been reported for microsporidia other than N. apis (CHU \& JAQUES, 1981 ; HeMBreE, 1982).

From the few samples prepared for microscopy it is not possible to make definite conclusions on where the infection first becomes established and where the first mature spores are produced. However, at least it is possible to state that the infection is not primarily spread from the anterior to the posterior parts of the ventriculus as suggested by LiU (1984). Mature spores and vegetative stages were found on the 4th day p.i. only in the hind part of the midgut (Fig. 4). From the preparations at 6 and 8 days p.i. it seemed as if the infection was spread from the posterior to the anterior parts of the ventriculus. This corroborates the findings of Kellner (1980). One sample indicated a primary infection more evenly spread throughout the epithelium. In no sample were the anterior parts more infected than the posterior parts. The early infection and transmission of the parasite in the epithelium should be studied further. It can be concluded from the present results that irrespective of infection dose, the whole ventriculus can become infected within 2 weeks, due to autoinfection.
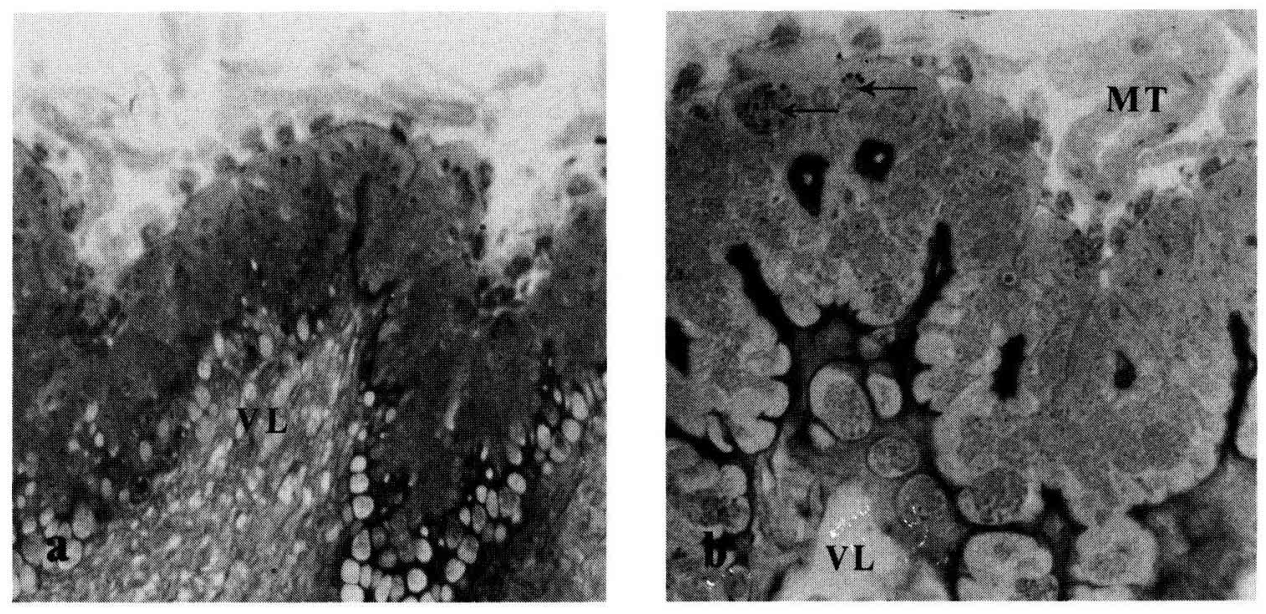

Fig. 4 a-b. - a) Part of the anterior ventricular epithelium 4 days p.i. with no infected cells visible. $\mathrm{VL}=$ ventricular lumen. b) Part of the posterior ventricular epithelium, same section as in a), with infected cells visible. Arrow $=$ infected cells with mature spores, MT $=$ Malpighian tubules. Magnification $\times 160$. 
The maximum spore count levels found in this investigation are slightly lower than those reported earlier. (LotmaR, 1940 ; 1943 ; Burnside \& Revell, 1948 ; BaILEY, 1981). The level of $2.5 \times 10^{8}$ spores in the ventriculus reported by WeISs (1984) seems improbable. The varying results presented emphasize the need for standardized methods in $N$. apis research as suggested by JACOBS (1979).

Received for publication in June 1987. Accepted for publication in July 1988.

\section{ACKNOWLEDGEMENTS}

The author wishes to thank Åsa Jansson, Department for Anatomy and Histology, Swedish University of Agricultural Sciences (SLU) for preparing histological advise and Prof. J. Pettersson, Department for Plant Pathology (SLU) for comments on the manuscript. The study had financial support from the Swedish Board of Agriculture.

\section{RÉSUMÉ \\ POUVOIR INFECTANT ET MULTIPLICATION DE NOSEMA APIS Z. DANS LE VENTRICULE DE L'ABEILLE}

Des ouvrières d'abeilles (Apis mellifica L.) âgées d'une semaine, regroupées par 100, reçurent individuellement des spores de Nosema apis aux doses suivantes : $6,25 \times 10^{3}, 6,25 \times 10^{2}, 6,25 \times 10^{1}$, $6,25 \times 10^{0}$ et $6,25 \times 10^{-1}$ spores/abeille. Un groupe de 100 abeilles ne reçut que du sirop à titre de témoin. Les abeilles étaient maintenues en étuve à $+30^{\circ} \mathrm{C}$.

On a dénombré les spores matures à l'aide d'un hémocytomètre du $1^{\text {er }}$ au $15^{\mathrm{e}}$ jour suivant l'infection (p.i.) ( $n=5$ abeilles/groupe). Des quantités détectables de spores furent produites le $4^{\mathrm{e}}$ jour p.i. La figure 1 montre l'augmentation journalière du nombre de spores matures chez le groupe qui avait reçu $6,25 \times 10^{3}$ spores/abeille. Le $15^{\mathrm{e}}$ jour p.i., le nombre moyen de spores par abeille infectée dépassait $18 \times 10^{6}$ dans tous les groupes où l'infection avait eu lieu. Le plus grand nombre de spores chez une abeille individuelle a été de $38,3 \times 10^{6}$.

La figure 2 prouve que, quelle que soit la dose d'infection, le même niveau d'infection est à peu près atteint en 2 semaines. De fortes doses de spores ont produit le stade complet d'infection légèrement plus tôt. La figure 3 donne le pourcentage d'abeilles infectées dans chaque groupe. Seule la dose de $6,25 \times 10^{3}$ spores/abeille a produit une infection à $100 \%$. On a calculé que la dose infectante moyenne était de 94,3 spores/abeille avec un intervalle de confiance de $95 \%$ entre 29,0 et 344,0 spores/abeille.

D'après les coupes histologiques préparées à partir des ventricules $2,4,6$ et 8 jours p.i., l'infection semble normalement se propager de la partie postérieure vers la partie antérieure du ventricule. 


\section{ZUSAMMENFASSUNG \\ INFEKTIOSITÄT UND VERMEHRUNG VON NOSEMA APIS Z. IM VENTRICULUS DER HONIGBIENE}

Gruppen von je 100 (eine Woche alten) adulten Arbeitsbienen (Apis mellifera) wurden individuell mit Sporen von Nosema apis in den Konzentrationen $6.25 \times 10^{3}, 6.25 \times 10^{2}, 6.25 \times 10^{1}, 6.25 \times 10^{0}$ und $6.25 \times 10^{-1}$ pro Biene gefüttert. Als Kontrolle wurden 100 Bienen nur mit Zuckersirup gefüttert. Die gekäfigten Bienen wurden im Brutschrank bei $30^{\circ} \mathrm{C}$ gehalten.

Vom 1. bis zum 15. Tag nach der Infektion (p.i.) wurden die reifen Sporen mit Hilfe eines Hämozytometers gezählt ( $\mathrm{n}=5$ Bienen pro Gruppe). Wahrnehmbare Sporenmengen wurden am 4. Tag p.i. produziert. In Abb. 1 ist die quantitative tägliche Zunahme an reifen Sporen in der Gruppe mit $6.25 \times 10^{3}$ Sporen pro Biene aufgezeichnet. Am 15. Tag p.i. war die mittlere Sporenzahl pro infizierte Biene bei allen Gruppen, in denen Infektion gefunden wurde, größer als $18 \times 10^{6}$. Die höchste Zahl an Sporen in einer Einzelbiene betrug $38.3 \times 10^{6}$.

Abb. 2 demonstriert, daß unabhängig von der Konzentration bei der Infektion nach 2 Wochen etwa die gleiche Infektionsrate in den infizierten Bienen erreicht wird. Hohe Konzentrationen erreichen das volle Infektionsstadium etwas eher. Der Prozentsatz infizierter Bienen in jeder Gruppe wird in Abb. 3 gezeigt. Nur die Konzentration $6.25 \times 10^{3}$ Sporen pro Biene produzierte eine $100 \%$ ige Infektion. Die mittlere infektiöse Konzentration wurde mit 94.3 Sporen pro Biene berechnet, wobei das $95 \%$ ige Vertrauensintervall von 29.0 bis 344.0 Sporen pro Biene reichte.

Bei histologischen Untersuchungen der Ventriculi nach 2, 4, 6 und 8 Tagen p.i. ergab sich, daß sich die Infektion normalerweise von den hinteren zu den vorderen Teilen des Ventriculus ausbreitet.

\section{REFERENCES}

Avery S.W., ANtony D.W., 1983. - Ultrastructural study of early development of Nosema algerae in Anopheles albimanus. J. Invertebr. Pathol., 42, 87-95.

Barley L., 1955. - The infection of the ventriculus of the adult honey bee by Nosema apis (Zander). Parasitology, 45, 86-94.

BaILeY L., 1959. - The natural mechanism of suppression of Nosema apis Z. in enzootically infected colonies of the honey bee, Apis mellifera Linnaeus. J. Insect Pathol., 1, 347-350.

Bailey L., 1968. - The measurement and interrelationships of infections with Nosema apis and Malpighamoeba mellificae of honey bee populations. J. Invertebr. Pathol., 12, 175-179.

Balley L., 1972a. - Nosema apis in drone honeybees. J. apic. Res., 11, 171-174.

BaILEY L., 1972b. - The preservation of infective microsporidian spores. J. Invertebr. Pathol., 20, 252254.

Bailey L., 1981. - Honey Bee Pathology. London, Academic Press.

Burnside C.E., Revell I.L., 1948. - Observation on nosema disease of honey bees. J. econ. Entomol., 41, 603-607.

CANTwelt. G.E., 1970 - Standard methods for counting nosema spores. Am. Bee J., 110, 222-223.

CHU W.H., JAQUES R.P., 1981. - Factors affecting infectivity of Vairimorpha necatrix (Microsporida : Nosematidae) in Trichoplusia ni (Lepidoptera : Noctuidae). Can. Entomol., 113, 93-102.

Fingler B.G., Nash W.T., Szabo T.I., 1982. - A comparison of two techniques for the measurement of nosema disease in honey bee colonies wintered in Alberta, Canada. Am. Bee J., 122, 369-371.

FinNey D.J., 1971. — Probit analysis, 3rd ed., London, Cambridge Univ. Press. 
Fries I., Еквонм G., Villumstad E., 1984. - Nosema apis, sampling techniques and honey yield. $J$. apic. Res., 23, 102-105.

Furgala B., Mussen E.C., 1978. - Protozoa. In : Honey bee pests predators and diseases. Ed. Morse R., Ithaca, Cornell Univ. Press, 63-77.

Gontarski H., Mebs D., 1964. - Eiweissfütterung und Nosemaentwicklung. Z. Bienenforsch., 7, 53-62.

Hembree S.C., 1982. - Dose-response studies of a new species of per os and vertically transmittable microsporidian pathogen of Aedes aegypti from Thailand. Mosquito News, 42, 55-61.

JacoBs F.J., 1979. - Eine standardisierte Methode zur Nosema-Forschung : eine Notwendigkeit im Labor und am Bienenstand. Apidologie, 10, 75-76.

Jacobs F.J., Kellner N., Van Der Worst E., 1978. - Ontwikkeling, diagnose en bestrijding van de nosemose bij de honingbij (Apis mellifera L.) Vlaams. Diergeneesk. Tijdschr., 47, 242-251.

Kellner N., 1980. - Studie van de levenscyclus van Nosema apis Zander in de honingbij (Apis mellifera L.). Thesis Fac. Sciences, State Univ. Gent, Belgium.

KelLner N., JACOBS F.J., 1978. - In hoeveel tijd bereiken de sporen van Nosema apis Zander de ventriculus van de honingbij (Apis mellifera L.) ? Vlaams. Diergeneesk. Tijdschr., 47, 252-259.

Kulincevic J.M., Rothenbuler W.C., Stairs G.R., 1973. - The effect of presence of a queen upon outbreak of a hairless-black syndrome in honey bee. J. Invertebr. Pathol., 21, 241-247.

L'Arrivé J.C.M., 1963. - The effect of sampling site on nosema determination. J. Insect Pathol., 5, 349-355.

L'Arrivée J.C.M., 1966. - Effets de la nosémose sur le rendement en miel. Can. Agric., 11, $24-25$.

Lehnert T., Shimanuki H., 1979. - Population change and nosema spore levels in colonies started with package bees. Apidologie, 10, 17-21.

Liv T.P., 1984. - Ultrastructure of the midgut of the worker honey bee Apis mellifera heavily infected with Nosema apis. J. Invertebr. Pathol., 44, 103-105.

Lotmar R., 1940. - Beiträge zur Pathologie des Bienendarmes C. Über den Infektionsverlauf und die Vermehrung des Parasiten Nosema apis (Quantitative Untersuchungen). Landw. Jb. Schweiz., 54, 775-805.

Lotmar R., 1943. - Über den Einfluss der Temperatur auf den Parasiten Nosema apis. Beih. Schweiz. Bienenztg., 1, 261-284.

Moffet J., WILson W.T., 1971. - The viability and infectivity of frozen nosema spores. Am. Bee J., $111,55,70$.

Morgenthaler O., 1963. - Die Keimung der Nosemasporen. Südwestdtsch. Imker, 15, 102-104.

Muresan E., Duca C., PAPAY Z., 1975. - The study of some histochemical indices of the midgut healthy and infected with Nosema apis Z. of the Apis mellifica carpatica bee. In Proc. XXVth Int. Apic. Congr., München, 1975, 384-385.

RAO C.R. 1973. - Linear statistical influence and its applications ; 2nd ed., New York, Wiley.

Rinderer T.E., ElliotT K.D., 1977. - Worker honey bee response to infection with Nosema apis: Influence of diet. $J$. econ. Entomol, 70, 431-433.

Van Laere O., Van Der Weghe L., Moermans R., Fordeyn D., 1980. - Quantitative determination of Nosema apis $\mathrm{Z}$. in the individual honey bee Apis mellifera L. Parasitica, 36, 68-73.

Verbeke M., JAcobs F.J., Rycke P.H. de, 1984. - Passage of various particles through the ventriculus in the honey bee (Apis mellifera L.). Am. Bee J., 123, 468-470.

WeIss K., 1984. - Bienen-Pathologie: Krankheiten, Schädlinge, Vergiftungen, gesetzliche Regelungen. München, Ehrenwirth.

Wilson G.C., 1983. - A dosing technique and the effects of sub-lethal doses of Nosema fumiferanea (Microsporida) on its host the spruce budworm, Choristoneura fumiferana. Parasitology, 87, 371-376. 